\title{
PHYSICAL ACTIVITY, PHYSICAL FITNESS AND ACADEMIC ACHIEVEMENT IN ADOLESCENTS: A SYSTEMATIC REVIEW
}

\author{
ATIVIDADEFISICA, APTIDÃO FISIICA EDESEMPENHO ACADÊMICO EM ADOLESCENTES: \\ UMA REVISÃO SISTEMÁTICA \\ ACTIVIDAD FÍSICA, APTITUD FÍSICA Y DESEMPEÑO ACADÉMICO EN ADOLESCENTES: \\ UNAREVISIÓN SISTEMÁTICA
}

Review Articie

ARTIGO DE REVISÃo Artículo de ReVISIÓN

\begin{abstract}
Cristiano Copetti Rodriguez ${ }^{1,2}$ (iD (Physical Education Professional) Edina Maria de Camargo 3 (ID (Physical Education Professional) Ciro Romelio Rodriguez-Añez ${ }^{4}$ (ID) (Physical Education Professional) Rodrigo Siqueira Reis 5,6 (DD (Physical Education Professional)
\end{abstract}

1.Universidade Tecnológica Federal do Paraná, Academic Department of Physical Education, Curitiba, PR, Brazil.

2.Universidade Federal do Paraná, Department of Physical Education, Curitiba, PR, Brazil.

3.Universidade Federal do Paraná, Physical Education Graduate Studies Program, Curitiba, PR, Brazil.

4.Universidade Tecnológica Federal do Paraná, Physical Education Graduate Studies Program, Curitiba, PR, Brazil.

5.Washington University in Saint Louis, Brown School, Prevention Research Center, Saint Louis, Missouri, USA.

6.Pontifícia Universidade Católica do Paraná, Urban Management Graduate Studies Program, Curitiba, PR, Brazil.

\section{Correspondence:}

Cristiano Copetti Rodriguez Rua Schiller, 555 Ap. 74, Alto da Rua XV, Curitiba, Paraná, PR, Brazil. 80045-240.cristiano.rodriguez@ hotmail.com

\begin{abstract}
Objetivo: Sintetizar as evidências disponíveis na literatura acerca da relação entre os componentes da atividade física, da aptidão física e o desempenho acadêmico em adolescentes. Métodos: A revisão seguiu os procedimentos metodológicos descritos pelo PRISMA e foi realizada nas bases de dados Lilacs, Medline, SciELO, PubMed, Web of Science e Science Direct. Foram incluídos estudos empíricos, de natureza quantitativa, publicados a partir do ano de 2006. Os descritores e palavras chave utilizados foram: "Motor activity", "Physical fitness,", "Physical activity", "Educational status", "Academic achievement", "Academic performance" e seus equivalentes em português e espanhol. Resultados: A aptidão física foi a variável mais investigada (45,5\%), seguida da atividade física (40,9\%), sendo que três estudos (13,6\%) investigaram ambas. Conclusão: Atividade física e aptidão física estão positivamente associadas ao desempenho acadêmico de adolescentes. Em mais de 80\% dos estudos a associação foi considerada forte. O componente da aptidão física mais frequentemente associado ao desempenho acadêmico foi a aptidão cardiorrespiratória. Nível de evidência ll; Revisão sistemática.
\end{abstract}

Descritores: Atividade motora; Desempenho acadêmico; Aptidão física; Adolescentes.

\section{RESUMO}

Objective: To synthesize the evidence available in the literature on the relationship between the components of physical activity, physical fitness and academic achievement in adolescents. Methods: The review followed the methodological procedures described by PRISMA and was carried out in the Lilacs, Medline, SciELO, PubMed, Web of Science and Science Direct databases. Quantitative empirical studies published as of 2006 were included. The following descriptors and keywords were used: "Motor activity", "Physical fitness", "Physical activity", "Educational status", "Academic achievement", "Academic performance", and their equivalents in Portuguese and Spanish. Results: The most widely investigated variable was physical fitness (45.5\%) followed by physical activity (40.9\%), whereas only three studies (13.6\%) investigated both. Conclusion: Physical activity and physical fitness are positively associated with the academic achievement of adolescents. In more than $80 \%$ of studies the association was considered strong. The physical fitness component most frequently associated with academic achievement was cardiorespiratory fitness. Level of evidence Il; Systematic review.

Keywords: Motor activity; Academic performance; Physical fitness; Adolescents.

\section{RESUMEN}

Objetivo: sintetizar las evidencias disponibles en la literatura sobre la relación entre los componentes de la actividad física, de la aptitud física y el desempeño académico en adolescentes. Métodos: La revisión siguió los procedimientos metodológicos descritos por PRISMA y se realizó en las bases de datos Lilacs, Medline, SciELO, PubMed, Web of Science y Science Direct. Se incluyeron estudios empíricos, de naturaleza cuantitativa, publicados a partir de 2006. Las palabras clave y los descriptores utilizados fueron: "Motor activity", "Physical fitness,", "Physical activity", "Educational status", "Academic achievement", "Academic performance", y sus equivalentes en portugués y español. Resultados: La aptitud física fue la variable más investigada (45,5\%), seguida de la actividad física (40,9\%), siendo que tres estudios (13,6\%) investigaron ambas. Conclusión: La actividad física y la aptitud física están positivamente asociados al desempeño académico de los adolescentes. En más de $80 \%$ de los estudios la asociación se consideró fuerte. El componente de la aptitud física más frecuentemente asociado al desempeño académico fue la aptitud cardiorrespiratoria. Nivel de evidencia ll; Revisión sistemática.

Descriptores: Actividad motora; Rendimiento académico; Aptitud física; Adolescentes. 


\section{INTRODUCTION}

A student's academic achievement (AA) can be influenced by the parents' education, socioeconomic status, and region of the country, among other teaching strategies adopted by the school. ${ }^{1-3}$ In addition to these, intervention studies have distinguished a positive association between physical activity (PA) and AA., ${ }^{4,5}$ The debate about the promotion of PA and physical fitness (PF) at school involves not only the positive effects on health-related aspects of children and adolescents, 5,6 but also their potential impact on $A A^{4,5,7,8}$ and on PA levels from childhood through to adult life. ${ }^{9}$

In this context, adolescents represent a group that requires greater attention and understanding, since it is at this stage that PA and physical fitness levels appear to rapidly decline. ${ }^{10}$ Therefore, increasing the exposure of young people to higher levels of PA in school can contribute both to health promotion ${ }^{9}$ and $A A .{ }^{11}$ Moreover, the positive influence of PA on the cognitive functions of children and adolescents is a relevant argument to justify the increase in time spent on physical education (PE) lessons and other opportunities for undertaking PA at school, without compromising on AA. PA can simultaneously provide an opportunity to directly benefit the health and AA of young people, 9,11 with the potential outcome of reducing school failure and dropout rates. ${ }^{4,5,7,8}$

To date, the systematic reviews published on the topic have shown results only for PA up to the year $2010,{ }^{11}$ or only for PF. ${ }^{12}$ When PA and PF were analyzed jointly, studies were limited to cardiorespiratory fitness ${ }^{13}$ or the age group of children. ${ }^{7}$ The available evidence does not show what has the greatest influence on AA (PA or PF). When investigating works published until 2010, Singh et al. identified a positive relationship between PA and AA in longitudinal articles, drawing attention to the low number of high quality articles. ${ }^{11}$ On the other hand, Marques et al. conclude that this relationship is inconsistent, particularly when PA is assessed by accelerometry. ${ }^{13}$ Other reviews have identified that cardiorespiratory fitness is positively associated with good $\mathrm{AA}_{1}^{12,13}$ demonstrating inconclusive results for muscle strength and flexibility. ${ }^{12}$ Therefore, it is necessary to ascertain to what extent the components of PA (intensity, frequency, time, type) and of PF (aerobic capacity, strength, flexibility and body composition) are related to AA, in addition to establishing the confounding variables most frequently reported in the literature, expanding knowledge of the topic.

Thus, the aim of this study was to synthesize the evidence available in the literature on the relationship between the components of physical activity, physical fitness and academic achievement in adolescents.

\section{MATERIALS AND METHODS}

The review followed the methodological procedures described by the Preferred Reporting Items for Systematic Reviews and Meta-Analyses (PRISMA), ${ }^{14}$ and was carried out by peers, in the Lilacs, Medline, SciELO, PubMed, Web of Science and Science Direct databases. The choice of databases was made according to subject.

With the intention of describing the most recent selection of evidence, quantitative empirical studies published as of 2006 and presenting information on the relationship between PA, PF and AA in adolescents (aged 12 to 18 years) were included. Review articles, opinions, letters to the editor, books, book chapters, research reports, dissertations and theses were excluded from the analysis.

The search was conducted in March 2018 with descriptors and keywords, so as not to compromise the scope of the search, combined with the Boolean operators "AND" and "OR". The terms were standardized by the Health Sciences Descriptors (DeCS) in Portuguese and Spanish and used in the Lilacs, Medline and SciELO databases. The corresponding terms in English, standardized by Medical Subject Headings (MeSH), were used in the PubMed, Web of Science and Science Direct databases. In addition, search filters for the target population (adolescents) were included in each database. The syntaxes used were as follows:

1. "atividade motora" OR "aptidão física" OR "atividade física" AND "escolaridade" OR "desempenho acadêmico" OR "rendimento escolar" OR "performance acadêmica".

2."motor activity" OR "physical fitness" OR "physical activity" AND"educational status" OR "academic achievement" OR "academic performance". 3. "actividad motora" OR "aptitud física" OR "actividad física" AND "escolaridad" AND "rendimiento académico" AND "rendimiento escolar".

The first stage consisted of the search for articles in the indexing databases $(n=5,962)$ and the exclusion of repeated titles. The titles were then read ( $n=5,783$ ) in order to identify articles related to the topic ( $n=86$ ). This was followed by the reading of abstracts, maintaining the research projects that presented information on AA, PA and/or PF $(n=45)$. The articles remaining at the end of these stages that satisfied the inclusion criteria totaled 22 (Figure 1).

The following information was extracted: authorship, year of publication, country of origin, year of collection, sample size, age of the subjects and study design. Articles that did not mention age, but mentioned the school grade of the adolescents, had the age bracket extrapolated by the authors, based on the school grade mentioned.

Information on the units of measurement of the dependent/independent variables and instruments used were also presented, along with a description of the studies with groups, providing details about the experiment (frequency, intensity, time, type and groups), as well as the main results of the relationship between $\mathrm{PA}, \mathrm{PF}$ and $\mathrm{AA}$, mentioning information related to the control variables and the statistical results obtained.

In addition, the selected articles were assessed for quality using an adapted scale. ${ }^{15}$ Among the 27 original items on the scale, 16 were evaluated for articles that were related to observational studies,

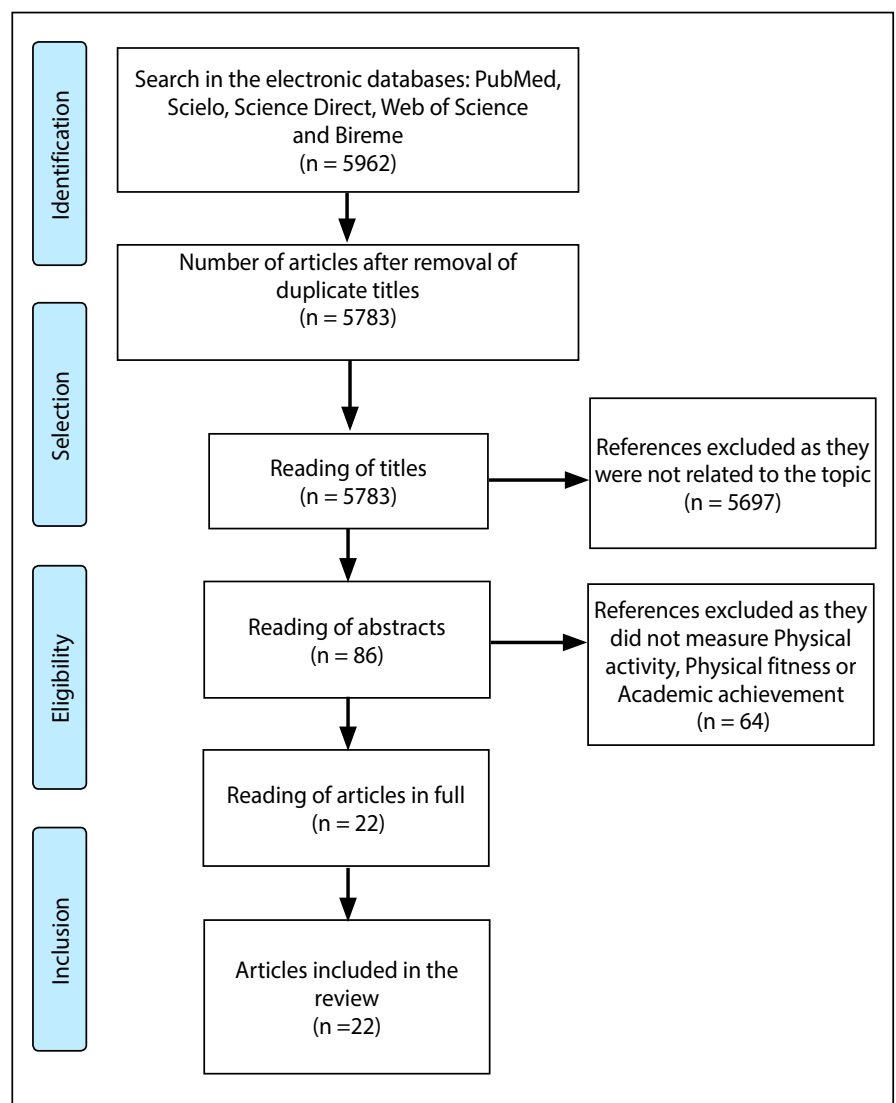

Figure 1. Stages of selection of the articles included in the systematic review on physical activity, physical fitness and academic achievement in adolescents, 2018. 
obtaining a score between 0 and 17 points (one of the items has a weight of two), and 27 for experimental studies, obtaining a score between 0 and 27. The items evaluated were: (1) quality of the description of hypotheses/objectives; (2) quality of the description of the outcome to be studied; (3) characterization of the included sample; (4) quality of the description of expositions of interest; (5) discussion of the main confounding factors; (6) quality of the description of the main outcomes of the study; (7) provision of estimates of random variability for the main findings; (8) adverse events (9) number of patients lost to follow-up; (10) presentation of the actual probability found; (11) selection and (12) inclusion of a representative sample; (13) representative or non-representative intervention site; (14) blinding of patients in relation to the intervention; (15) evaluators with no knowledge of the evaluation; (16) analysis of the main results; (17) follow-up time; (18) appropriation of the statistical tests used to measure the main outcomes; (19) expositions without classification errors; (20) accuracy of the instruments used for the main outcomes; (21) recruitment; (22) same recruitment period; (23) randomization; (24) confidential random allocation; (25) adequacy of the adjustment for the main confounding factors; (26) losses to follow-up; (27) adequacy of the statistical power to detect an important effect, with a significance level of $5 \%$. The sum of the items was considered as the absolute quality index and the relative index was used to characterize studies with higher or lower quality.

In addition, Cohen's d was calculated to standardize the comparison of results, thus enabling a better comparison of the strength of association of each study. ${ }^{16}$ This measure was taken due to the considerable variety of statistical procedures. The results were then classified in small, medium and large effect size, according to the analysis employed. ${ }^{16}$ The lack of information on data in the analyses, in some studies (7), precluded an effect size calculation.

\section{RESULTS}

Twenty-two articles fulfilled the criteria and were included in this study. Approximately one in three articles was published between 2016 and 2018, with a greater proportion of studies carried out on sample groups of adolescents from the United States (27.3\%), Chile (18.2\%) and Spain (13.6\%). Sample size ranged from 67 to 254,743 adolescents, 14 studies used a cross-sectional design (63.6\%), while six studies used a longitudinal design, as follows: three retrospective cohort studies (13.6\%), three prospective cohort studies (13.6\%) and two studies with an experimental design, of the group-/class-randomized trial type (9.1\%). All studies included male and female adolescents in the sample and used quantitative methods. As regards the quality of the studies, $86.3 \%$ fulfilled at least $80 \%$ of the quality items suggested by the scale. Further information on the characteristics of the studies is presented in Table 1.

AA was assessed in most studies (54.5\%) by academic grades. The rest of the studies assessed AA based on standardized tests (45.5\%), with protocols differing according to the country and/or region. In the United States, the following tests were used: New York State Testing Program, 21,31 CST (California Standardized Test), ${ }^{26}$ MEAP (Michigan Educational Assessment Program) ${ }^{29}$ and TAKS (Texas Assessment of Knowledge and Skill). ${ }^{27}$ Chile used the SIMCE (System for the Assessment of Educational Quality Test) ${ }^{20,32,35}$ and Taiwan measured academic achievement based on the score of a test for admission to higher education, GSAT (General

Table 1. Characteristics of the studies selected in the systematic review on physical activity, physical fitness and academic achievement in adolescents ( $n=22$ ).

\begin{tabular}{|c|c|c|c|c|c|c|c|c|c|}
\hline Author & Year & PA/PF & Country & Year of collection & $\mathrm{n}$ & Age & Design & Quality of studies ${ }^{\mathrm{a}}$ & $\%^{b}$ \\
\hline Sigfusdottir et al. ${ }^{17}$ & 2007 & PA & Iceland & 2000 & 5,810 & 14 to 15 & Cross-sectional & 15 & 93.8 \\
\hline 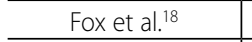 & 2010 & PA & USA & 1998-1999 & 4,746 & 11 to 18 & Cross-sectional & 14 & 87.5 \\
\hline Stea and Torstveit. ${ }^{19}$ & 2014 & $\mathrm{PA}$ & Norway & N/A & 2,432 & 15 to 17 & Cross-sectional & 14 & 87.5 \\
\hline Correa-Burrows et al. ${ }^{20}$ & 2014 & PA & Chile & 2010 & 620 & 14 to 15 & Cross-sectional & 14 & 87.5 \\
\hline Phillips et al. ${ }^{21}$ & 2015 & PA & USA & $2009-2010$ & 72 & 14 to 15 & $\begin{array}{l}\text { Quasi-experimental } \\
\text { (no control group) }\end{array}$ & 22 & 81.5 \\
\hline Bastos et al. ${ }^{22}$ & 2015 & $\mathrm{PA}$ & Portugal & N/A & 490 & 12 to 18 & Cross-sectional & 14 & 87.5 \\
\hline Faught et al..$^{23}$ & 2017 & $\mathrm{PA}$ & Canada & 2014 & 28608 & 11 to 15 & Cross-sectional & 15 & 93.8 \\
\hline $\begin{array}{c}\text { Garcia-Hermoso } \\
\text { and Marina }{ }^{24}\end{array}$ & 2017 & PA & Chile & 2014 & 395 & 12 to 13 & Cross-sectional & 14 & 87.5 \\
\hline Owen et al. ${ }^{25}$ & 2018 & PA & Australia & 2014-2015 & 2,194 & $M=12.98 / M=14.12$ & $\begin{array}{c}\text { Longitudinal } \\
\text { Prospective Cohort }\end{array}$ & 15 & 93.8 \\
\hline London et al. ${ }^{26}$ & 2011 & PF & USA & $\begin{array}{l}2002-2003 \\
2007-2008 \\
\end{array}$ & $\begin{array}{l}1,325 \\
1,410 \\
\end{array}$ & $\begin{array}{l}09 \text { to } 13 \\
11 \text { to } 15 \\
\end{array}$ & \begin{tabular}{|c|} 
Longitudinal \\
Retrospective Cohort \\
\end{tabular} & 15 & 93.8 \\
\hline Van Dusen et al. ${ }^{27}$ & 2011 & PF & USA & $2007-2008$ & 254.743 & 8 to 17 & Cross-sectional & 15 & 93.8 \\
\hline Chen el al. ${ }^{28}$ & 2013 & PF & Taiwan & 2008-2010 & 669 & $M=14.6$ & $\begin{array}{c}\text { Longitudinal } \\
\text { Prospective Cohort }\end{array}$ & 14 & 87.5 \\
\hline Coe et al. ${ }^{29}$ & 2013 & PF & USA & 2008 & 1,701 & 08 to 15 & Cross-sectional & 14 & 87.5 \\
\hline Liao et $a l .^{30}$ & 2013 & PF & Taiwan & $2009-2011$ & 149.240 & 17 to 18 & $\begin{array}{c}\text { Longitudinal } \\
\text { Retrospective Cohort }\end{array}$ & 13 & 81.3 \\
\hline Bezold et al. ${ }^{31}$ & 2014 & PF & USA & $\begin{array}{l}2006-2007 \\
2010-2011 \\
\end{array}$ & 83.111 & 11 to 14 & $\begin{array}{c}\text { Longitudinal } \\
\text { Retrospective Cohort }\end{array}$ & 15 & 93.8 \\
\hline $\begin{array}{c}\text { Olivares and } \\
\text { Garcia-Rubio. }^{32} \\
\end{array}$ & 2016 & PF & Chile & 2011 & 18746 & $M=13.8$ & Cross-sectional & 13 & 81.3 \\
\hline Castro and Oliveira. ${ }^{33}$ & 2016 & PF & Brazil & 2015 & 326 & 15 to 18 & Cross-sectional & 13 & 81.3 \\
\hline Castro Lopez et al. ${ }^{34}$ & 2016 & $\mathrm{PF}$ & Spain & $\mathrm{N} / \mathrm{A}$ & 338 & $M=14 \pm 1.3$ & Cross-sectional & 12 & 75.0 \\
\hline $\begin{array}{c}\text { Garcia-Hermoso } \\
\text { et al. }{ }^{35}\end{array}$ & 2017 & PF & Chile & $2011,2013,2014$ & 36870 & $M=13.83$ & Cross-sectional & 13 & 81.3 \\
\hline Ardoy et al. ${ }^{36}$ & 2014 & PA/PF & Spain & 2007 & 67 & 12 to 14 & $\begin{array}{c}\text { Experimental (with } \\
\text { control group) }\end{array}$ & 20 & 74.0 \\
\hline $\begin{array}{c}\text { Pellicer-Chenoll } \\
\text { et al. }{ }^{37} \\
\end{array}$ & 2015 & PA/PF & Spain & 2007-2011 & 444 & 16 to 17 & $\begin{array}{c}\text { Longitudinal } \\
\text { Prospective Cohort }\end{array}$ & 12 & 75.0 \\
\hline Oliveira et al. ${ }^{38}$ & 2017 & PA/PF & Portugal & N/A & 640 & $M=13,35 \pm 2.5$ & Cross-sectional & 13 & 81.3 \\
\hline
\end{tabular}

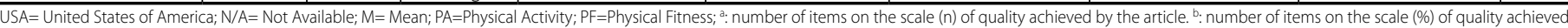
by the article 
Scholastic Ability Test), ${ }^{30}$ which is equivalent to the SAT (Scholastic Aptitude Test) in the United States, or ENEM (Exame Nacional do Ensino Médio - National High School Examination) in Brazil.

Of the studies that investigated PA, $88.8 \%$ used questionnaires to assess this variable: Questionnaire created by Prochaska, Sallis \& Long; ${ }_{2}^{22}$ Godard, et al.:20 Leisure Time Exercise Questionnaire; ${ }^{18}$ PAQ-A, ${ }_{1}^{24}$ PAQ $^{37}$ and another created and validated for the study. ${ }^{17}$ Only two articles assessed PA objectively. $25,38 \mathrm{PF}$ was the independent variable most frequently investigated (45.5\%), followed by PA (40.9\%), and three studies (13.6\%) measured both. ${ }^{36-38}$ Among the 13 articles that investigated PF, the test battery used most often was FITNESSGRAM, 26,27,29,31 followed by the EUROFIT ${ }^{34}$ battery, while the rest used single miscellaneous tests $28,30,32,33,35-38$ (Table 2).
The most frequent confounding variables were socioeconomic status (SES) (45.5\%), nutritional status (45.5\%), sex (36.4\%) and age (27.3\%). All articles included in this review showed a positive gross association between PA and/or PF and AA. Among the 15 articles that made adjustments for confounding variables, ${ }^{17-20,23-25,28,29,31-33,35,38} 93.3 \%$ continued to show a significant association between PA, PF and AA after adjustment. 17-20,23,25,28,29,31-33,35,38

Approximately half of the articles (10) presented results stratified by sex. $18,19,21,24-27,30,31,34$ Of these studies, $10 \%$ suggest a greater association of PA/PF with academic achievement for boys, ${ }^{21}$ while $70 \%$ of studies suggest a greater association of PA/PF with academic achievement for girls. 18,19,24-26,30,34 Furthermore, 20\% of studies that stratified results according to sex did not identify differences in results between boys and girls. ${ }^{27,31}$

Table 2. Instruments and units of measurement of the independent and dependent variables $(n=22)$.

\begin{tabular}{|c|c|c|c|c|c|}
\hline Author & Year & $\begin{array}{l}\text { PA/ } \\
\text { PF }\end{array}$ & $\begin{array}{c}\text { Instrument used to collect } \\
\text { independent variables }\end{array}$ & $\begin{array}{c}\text { Unit of measurement of the } \\
\text { independent variables }\end{array}$ & Measure of academic achievement \\
\hline Sigfusdottir et al. ${ }^{17}$ & 2007 & PA & Questionnaire & $\begin{array}{l}\text { PA level (Score from } 1 \text { to } 6 \text { - almost never, } \\
\text { less than } 1 x / \text { week, } 1 x / \text { week, } 2 \text { to } 3 x / \text { week, } \\
4 \text { to } 5 x / \text { week and almost every day) }\end{array}$ & Academic grades \\
\hline Fox et al. ${ }^{18}$ & 2010 & PA & $\begin{array}{c}\text { LTEQ (Leisure Time } \\
\text { Exercise Questionnaire) }\end{array}$ & PA level (minutes/week) & Academic grades \\
\hline Stea and Torstveit. ${ }^{19}$ & 2014 & PA & Questionnaire & 2 categories of hours/week & Academic grades \\
\hline Correa-Burrows et al. ${ }^{20}$ & 2014 & PA & $\begin{array}{l}\text { PA Questionnaire } \\
\text { (Godard; et al, 2008) }\end{array}$ & PA level (minutes/week) & $\begin{array}{c}\text { SIMCE (System for the Assessment } \\
\text { of Educational Quality Test) }\end{array}$ \\
\hline Phillips et al. ${ }^{21}$ & 2015 & PA & Questionnaire & $\begin{array}{l}\text { PA level (minutes/week), } \\
\text { Physical Education lesson }\end{array}$ & The New York State Testing Program \\
\hline Bastos et al. ${ }^{22}$ & 2015 & PA & $\begin{array}{c}\text { PA Questionnaire } \\
\text { (Prochaska, Sallis \& } \\
\text { Long, 2001) }\end{array}$ & PA level (minutes/week) & Academic grades \\
\hline Faught et al..$^{23}$ & 2017 & PA & Questionnaire & Days/week & Academic grades (Self-reported) \\
\hline Garcia-Hermoso and Marina. ${ }^{24}$ & 2017 & PA & PAQ-A & PA level (score from 1 to 5 ) & Academic grades \\
\hline Owen et al. ${ }^{25}$ & 2018 & PA & Accelerometry & Counts & $\begin{array}{c}\text { NAPLAN (National Assessment } \\
\text { Program - Literacy and Numeracy) }\end{array}$ \\
\hline London et al. ${ }^{26}$ & 2011 & PF & FITNESSGRAM & $\begin{array}{c}\text { PF Score } \\
\text { (4 categories) }\end{array}$ & $\begin{array}{c}\text { CST (California Standardized Test)/ } \\
\text { ELA (English Language Arts }\end{array}$ \\
\hline Van Dusen et al. ${ }^{27}$ & 2011 & PF & FITNESSGRAM & $\begin{array}{c}\text { Interquintile } \\
\text { PF } \\
\end{array}$ & $\begin{array}{c}\text { TAKS (Texas Essential } \\
\text { Knowledge and Skills) }\end{array}$ \\
\hline Chen et al. ${ }^{28}$ & 2013 & PF & $\begin{array}{l}\text { 1600/800 run test } \\
\text { Sit and reach } \\
\text { Bent leg curl up } \\
\text { BMI }\end{array}$ & $\begin{array}{c}\text { VO2max (ml/kg/min) } \\
\text { Centimeters } \\
\text { Repetitions } / 1 \text { minute } \\
\text { Weight }(\mathrm{kg}) / \text { Height (meters) }\end{array}$ & Academic grades \\
\hline Coe et al. ${ }^{29}$ & 2013 & PF & FITNESSGRAM & $\begin{array}{c}\text { PF Score } \\
(0 \text { to } 5) \\
\end{array}$ & $\begin{array}{c}\text { MEAP (Michigan Education } \\
\text { Assessment Program) }\end{array}$ \\
\hline Liao et al..$^{30}$ & 2013 & PF & $\begin{array}{l}\text { 1600/800 run test } \\
\text { Sit and reach } \\
\text { Bent leg curl up } \\
\text { Jumping distance }\end{array}$ & $\begin{array}{c}\text { VO2max (ml/kg/min) } \\
\text { Centimeters } \\
\text { Repetitions/1 minute } \\
\text { Centimeters }\end{array}$ & $\begin{array}{c}\text { GSAT (General Scholastic } \\
\text { Assessment Test) }\end{array}$ \\
\hline Bezold et al. ${ }^{31}$ & 2014 & PF & FITNESSGRAM & Percentile of PF score (\%) & The New York State Testing Program \\
\hline Olivares and Garcia-Rubio. ${ }^{32}$ & 2016 & PF & SIMCE & VO2max(ml/kg/min) & $\begin{array}{l}\text { SIMCE (System for the Assessment } \\
\text { of Educational Quality Test) }\end{array}$ \\
\hline Castro and Oliveira ${ }^{33}$ & 2016 & $\mathrm{PF}$ & $\begin{array}{l}\text { Sit and reach } \\
1609 \text { m test } \\
\text { Abdominal test }\end{array}$ & $\begin{array}{c}\text { Centimeters } \\
\mathrm{VO}_{2} \mathrm{max}(\mathrm{ml} / \mathrm{kg} / \mathrm{min}) \\
\text { Repetitions } / 1 \text { minute }\end{array}$ & Academic grades \\
\hline Castro Lopez et al. ${ }^{34}$ & 2016 & PF & EUROFIT & $\begin{array}{c}\text { PF Score } \\
(5 \text { groups })\end{array}$ & Academic grades \\
\hline Garcia-Hermoso et al. ${ }^{35}$ & 2017 & PF & SIMCE & $\mathrm{VO}_{2} \max (\mathrm{ml} / \mathrm{kg} / \mathrm{min})$ & $\begin{array}{c}\text { SIMCE (System for the Assessment } \\
\text { of Educational Quality Test) }\end{array}$ \\
\hline Ardoy et al. ${ }^{36}$ & 2014 & $\begin{array}{l}\text { PA } \\
\text { PF }\end{array}$ & $\begin{array}{l}\text { 20m Shuttle run } \\
4 \times 10 \text { m shuttle run } \\
\text { Standing long jump } \\
\end{array}$ & $\begin{array}{c}\mathrm{VO}_{2} \max (\mathrm{ml} / \mathrm{kg} / \mathrm{min}) \\
\text { Seconds and hundredths } \\
\text { Centimeters }\end{array}$ & Academic grades \\
\hline Pellicer-Chenoll et al. ${ }^{37}$ & 2015 & $\begin{array}{l}\text { PA/ } \\
\text { PF }\end{array}$ & $\begin{array}{c}\text { IPAQ } \\
\text { Jump power } \\
\text { Cooper test } \\
\text { Handgrip isometric strength } \\
\text { IMC } \\
\end{array}$ & $\begin{array}{c}\text { PA level (minutes/week) } \\
\text { Centimeters } \\
\mathrm{VO}_{2} \text { max (ml/kg/min) } \\
\text { Kilogram }(\mathrm{kg}) \\
\text { Weight }(\mathrm{kg}) / \text { height (meters) } \\
\end{array}$ & Academic grades \\
\hline Oliveira et al. ${ }^{38}$ & 2017 & $\begin{array}{l}\mathrm{PA} \\
\mathrm{PF}\end{array}$ & $\begin{array}{c}\text { 20m Shuttle Run } \\
\text { Accelerometry }\end{array}$ & $\begin{array}{c}\mathrm{VO}_{2} \max (\mathrm{ml} / \mathrm{kg} / \mathrm{min}) \\
\text { Counts }\end{array}$ & Academic grades \\
\hline
\end{tabular}


In three studies, when stratifying the analyses by sex, boys stopped showing an association. ${ }^{24-26}$ The studies that investigated PF as an independent variable, showed, in $40 \%$ of the studies, that the result does not differ between boys and girls. However, $60 \%$ of the studies showed a strong association between PF and AA for girls.

When considering only studies that analyzed components of physical fitness ( $n=9),{ }^{27,30,32,33,35,37,38}$ the investigations demonstrated that cardiorespiratory fitness (77.8\%), 27,28,32,33,35,37,38 muscle strength $(66.7 \%), 27,29,32,33,35,37$ flexibility $(33.3 \%)^{27,30,32}$ and muscle power $(22.2 \%)^{30,37}$ were associated with $A A$. As regards the studies that analyzed PA $(n=12),{ }^{17-25,37-38}$ the components most closely associated with good AA were: volume in minutes/week or kcal/day (66.7\%), ${ }_{17-20,22,24,25,37}$ frequency in days/week (16.7\%), ${ }^{23,36}$ post-intervention time to perform an academic activity (8.3\%), ${ }^{21}$ and intensity of the activity performed (8.3\%). ${ }^{36}$

Based on the studies that presented sufficient data to calculate the effect size (15 articles), irrespective of the type of design, the studies consistently show that there is a positive association between PF and PA levels and AA. When investigating the relationship between PF and AA (5 studies), ${ }^{23,28,33-35} 80 \%$ of studies had a large effect size. ${ }^{23,28,33,35}$ When investigating the relationship between PA and AA (8 studies), 18-21,23-25,30 75\% of them had a large effect size. ${ }^{18-21,24,30}$ The two studies that investigated PF and PA together with AA and offered sufficient data for the calculation ${ }^{37,38}$ had a large effect size. The results did not vary in relation to the type of design or according to the sample number, because regardless of the study design, the association between the variables PF/PA and AA was positive.

Three studies quantified AA according to academic grade values. ${ }^{28,31,36}$ The increase in the frequency of PE classes from two to four times a week with an intensity $>120$ beats per minute (bpm), average of $147 \mathrm{bpm}$, improved the overall AA for $96 \%$ of the students. ${ }^{36}$ The improvement in PF, for the "excellent" rating of the normative test table, increased the academic grades of those who achieved this classification by 20 percentile points or more. ${ }^{31}$ Moreover, the maintenance and/or improvement of cardiorespiratory fitness levels, adjusted by the confounding variables, accounted for $17.3 \%$ of the improvement in AA in grades. ${ }^{28}$ The main results of each study are described in Table 3.

\section{DISCUSSION}

The aim of this study was to synthesize the evidence available in the literature on the relationship between the components of physical activity, physical fitness and academic achievement in adolescents. There has been an increase in the number of publications since 2015. Most studies are from the United States and Europe, corroborating the existence of a gap in this topic in low and middle income countries. ${ }^{20,33}$ Most have a cross-sectional design, hence it is not possible to rule out reverse causality as a limitation of the findings. All studies in this review showed a positive association between PA and/or PF and AA. However, part of the studies had a longitudinal design, and the results did not differ from the cross-sectional studies, supporting the hypothesis that the relationship may be causal.

AA was assessed through academic grades or standardized tests adapted to the situation of each country. This limits comparisons between countries. Nevertheless, since the outcome is measured in a standardized manner, any problems with classification bias are mitigated, which reinforces the internal validity of the studies. PF was analyzed in an objective and standardized manner. However, PA was assessed through self-reported measures, which have less sensitivity and precision and limit the comparison. ${ }^{39}$ Accordingly, there is a greater chance of classification errors for PA when compared to studies that used PF as an independent variable. The absence of studies that simultaneously analyze PA and PF, limits the understanding of these expositions since PA and PF are independent predictors of several aspects of adolescent health ${ }^{40}$ and development. ${ }^{18,22,28,29}$

The main confounding variables analyzed were socioeconomic status, sex and nutritional status, and were used in the adjusted analyses, demonstrating that they moderate this relationship. A study carried out in the state of São Paulo, which included the 1,000 best schools, showed that the higher the monthly tuition fees, the higher the students' scores in ENEM, even after adjusting for family background, indicating that the more expensive the tuition, the higher the AA. ${ }^{3}$ Another study conducted with data from the Elementary School Assessment System considering socioeconomic variables of schools and parents, showed that $79 \%$ of the variance between schools can be attributed to socioeconomic composition, with the parents' education exerting a strong influence. ${ }^{2}$ Therefore, socioeconomic variables, both of schools and of parents, should be considered when interpreting associations. Consequently, we suggest using these variables in future research, in addition to other psychosocial variables such as self-confidence, social support and readiness for participation in PA, as a way of seeking to better understand how all these variables are interrelated in the association between PA, PF and AA.

Most of the studies assessed AA based on academic grades, yet the method of quantification varies from country to country, which may constitute a trend bias in the analyses. ${ }^{17,18,22,28,33,34,36,37}$ High-income countries used similar standardized tests (United States, Chile and Taiwan). The standardized tests showed adequate reliability (test-retest between $r=0.81$ and $r=0.93)^{27}$ and internal consistency (Alpha between 0.83 and 0.89). ${ }^{21}$ These tests are consistent with the situation in schools, ${ }^{21,27}$ and enable an analysis between different school grades and years. ${ }^{30,31}$ Two studies opted to standardize the results in percentiles and Z-score, respectively. ${ }^{26,29}$ Although standardized scales allow comparisons in analyses, they are not yet widely used, which limits the comparison between studies, since academic grades do not follow the same assessment standard.

PA and PF are rarely measured simultaneously. Therefore, there is scant evidence about the weight of each one, when assessed together with AA. Systematic reviews published on the topic present results independently ${ }_{i}^{11,12}$ when PA and PF were analyzed in conjunction, studies were limited to the cardiorespiratory fitness ${ }^{13}$ or age bracket of children.?

We identified three works (13.6\%) that assessed PA and PF simultaneaously. ${ }^{36-38}$ Of these, one identified a positive association with AA only for $\mathrm{PF}^{38}$ another only for $\mathrm{PA}^{36}$ and the third for both variables. ${ }^{37} \mathrm{~A}$ randomized study analyzed the frequency and intensity of physical education lessons on the performance of two academic tests, one involving mathematics and the other language. The results showed no difference in AA between lessons held twice a week compared to lessons held 4 times a week, and $\mathrm{HR}<120$ beats per minute, but revealed a difference when the intensity was> 120 beats per minute. ${ }^{36}$ Suggesting that PA is related to $A A$, however, the weekly volume alone does not seem to cause any change, requiring the combination of volume and intensity.

As regards to $P F, A A$ and sex, the studies included in this review showed a significant positive association for girls ${ }^{30,34}$ and for both sexes. ${ }^{31}$ However, the effect was greater for boys than for girls. ${ }^{31}$ Performance on a mathematics test was higher for boys $(6.11 \pm 2.24)$ than for girls $(5.17 \pm 2.52) .{ }^{21}$ Although sex acted as a moderator of results in the articles cited, this effect may not be the same in other groups, since the methodology of the studies and the variables of PF are not the same. Similarly, in the review published by Santana et al. ${ }^{12}$ in 2016, which synthesized articles with PF and AA, we found one study that showed an association only for boys and three that showed a strong association for 
Table 3. Characterization and main results of the studies analyzed $(n=22)$.

\begin{tabular}{|c|c|c|c|c|}
\hline $\begin{array}{l}\text { Author } \\
\text { (Year) }\end{array}$ & $\mathrm{PA} / \mathrm{PF}$ & $\begin{array}{l}\text { Description of the } \\
\text { experimental studies }\end{array}$ & Main results & $\begin{array}{l}\text { Effect or/ } \\
\text { regression } \\
\text { coefficient }\end{array}$ \\
\hline $\begin{array}{r}\text { Sigfusdottir } \\
\text { et al. }(2007)^{17} \\
\end{array}$ & PA & NA & $\begin{array}{c}\text { Body mass, diet and PA explain } 24 \% \text { of the variation in AA when controlled } \\
\text { by gender, parental education, family structure and absenteeism. }\end{array}$ & NA \\
\hline $\begin{array}{l}\text { Fox et al. } \\
(2010)^{18}\end{array}$ & PA & NA & $\begin{array}{l}\text { Adjustment for SES, race/ethnicity. In high school girls hours of moderate/vigorous PA ( } t=4.54 \text {; } \\
p<0.001) \text { and participation in sports teams }(t=5.99 ; p<0.001) \text { were independently associated } \\
\text { with higher AA. In boys only participation in sports teams was significant }(t=6.41 ; p<0.001) \text {. }\end{array}$ & Large \\
\hline $\begin{array}{l}\text { London et } \\
\text { al. }(2011)^{26}\end{array}$ & PF & NA & $\begin{array}{l}\text { Girls had better scores only in English language }(B=0.084 ; p<0.05) \text {. Variables associated with math } \\
\text { and English grades were: Passing in the two } P F \text { tests }(B=0.218 \text { and } 0.154 ; p<0.001) \text {, Non-Hispanic } \\
\text { White }(B=0.237 ; p<0.01 / B=0.391 ; p<0.001) \text {, Be learning English }(B=-0.660 \text { and } 0.820 ; p<0.001) \\
\text { Special education }(B=-0.560 \text { and }-0.640 ; p<0.001) \text {, Reduced lunch break time }(B=-0.270 \text { and } \\
-0.3 ; p<0.001) \text { and Parents with higher education }(B=0.269 p<0.001 \text { and } B=0.128 ; p<0.01) \text {. }\end{array}$ & NA \\
\hline $\begin{array}{l}\text { Van Dusen } \\
\text { et al. }(2011)^{27}\end{array}$ & PF & NA & $\begin{array}{l}\text { PF positively associated with the scores of the reading }(p<0.05) \text { and math } \\
\text { tests }(p<0.001) \text { after adjustment for sociodemographic variables. }\end{array}$ & Large \\
\hline $\begin{array}{c}\text { Chen et al. } \\
(2013)^{28}\end{array}$ & $\mathrm{PF}$ & NA & $\begin{array}{l}\text { PF and change in weight, controlled by sex and } \\
\text { SES, were associated with AA ( } p=0.001 \text { and } p=0.003 \text { respectively). } \\
\text { These variables explained the variation in AA (17.3\%). }\end{array}$ & Large \\
\hline $\begin{array}{l}\text { Coe et al. } \\
(2013)^{29}\end{array}$ & PF & NA & A positive association was found between PF and AA ( $p<0.005)$, irrespective of SES. & NA \\
\hline $\begin{array}{l}\text { Liao et al. } \\
(2013)^{30}\end{array}$ & PA & NA & $\begin{array}{l}\text { The change in the combined PF score during the high school years with } \\
\text { the scores of the college/university admission examination were positively } \\
\text { associated, with a stronger relationship for female students }(p<0.05) \text {. }\end{array}$ & Large \\
\hline $\begin{array}{c}\text { Ardoy et al. } \\
(2014)^{36}\end{array}$ & $\mathrm{PA} / \mathrm{PF}$ & $\begin{array}{l}\text { PE at school, } C G=2 \times / \text { week } \\
55 \text { min. } E G 1=4 \times / \text { wk } 55 \\
\text { min. } E G 2=4 \times / \text { wk } 55 \mathrm{~min} \\
\text { high intensity }(>120 \mathrm{bpm})\end{array}$ & $\begin{array}{l}\text { AA was not associated with PF (adjusted for maturation, sex, frequency of lessons, and baseline } \\
\text { values) considering the total } n \text { of the sample (all groups together). AA had a significant } \\
\text { association for the } E G 2 \text { group (considering the academic grades for mathematics } p=0.02 \text {; } \\
\text { other disciplines } p=0.001 \text { ). } 96 \% \text { of students had improvements in their academic grades. }\end{array}$ & NA \\
\hline $\begin{array}{l}\text { Bezold et } \\
\text { al. }(2014)^{31}\end{array}$ & PF & NA & $\begin{array}{l}\text { Both boys }(+0.38 \text { percentage points/year }-95 \% \mathrm{Cl}) \text { and girls }(+0.36 \text { percentage points / } \\
\text { year }-95 \% \mathrm{Cl} \text { ) who improved their PF levels improved their scores on the academic test } \\
\text { when compared with the reference group. Boys }(-0.55 \text { percentage points/year }-95 \% \\
\mathrm{Cl}) \text { and girls }(+0.40 \text { percentage points/year }-95 \% \mathrm{Cl} \text { ) who had a worse PF level also } \\
\text { had worse scores on the academic test compared to the control group. The analysis } \\
\text { was adjusted for obesity, aptitude, income, language spoken, and place of birth. }\end{array}$ & NA \\
\hline $\begin{array}{l}\text { Correa- } \\
\text { Burrows et } \\
\text { al. }(2014)^{20}\end{array}$ & PA & NA & $\begin{array}{l}\text { The chance of having a good sufficiency (OR=2.3 95\% Cl:1.3-4.2) or proficiency score (OR=2.9 95\% } \\
\text { Cl:1.9-4.6) was twice as high for physically active students compared to students who participate } \\
\text { in <2h/week of regular PA. When adjusted by sex, nutritional status, SES and type of school, it } \\
\text { was associated with more than } 4 \mathrm{~h} / \mathrm{wk} \text {, being male and high school quality ranking ( } \mathrm{p}<0.001) \text {. }\end{array}$ & Large \\
\hline $\begin{array}{l}\text { Stea and } \\
\text { Torstveit } \\
(2014)^{19}\end{array}$ & PA & NA & $\begin{array}{l}\text { Girls }(\mathrm{OR}=1,51) \text { and boys }(\mathrm{OR}=1.39) \text { who accumulated a greater number of hours of PA per week had } \\
\text { a greater chance of achieving better school grades, when compared to classmates who engage in } \\
\text { PA less frequently. Likewise, active commuting was also associated with better academic grades for } \\
\text { girls }(\mathrm{OR}=1.51) \text { and boys }(\mathrm{OR}=1.72) \text {. The analyses were adjusted for } \mathrm{BMl} \text { and parental education. }\end{array}$ & Large \\
\hline $\begin{array}{r}\text { Bastos et } \\
\text { al. }(2015)^{22} \\
\end{array}$ & PA & NA & $\begin{array}{l}\text { AA in PE was positively associated with participation in PA }(r=0.25 p<0.001) \text {. Frequency of } \\
\text { federated sports had a positive association with the final average }(r=0.11 p<0.05) .\end{array}$ & NA \\
\hline $\begin{array}{l}\text { Pellicer- } \\
\text { Chenoll et } \\
\text { al. }(2015)^{37}\end{array}$ & PA/PF & NA & $\begin{array}{l}\text { All the indicators of PF (aerobic test, strength, jump) and PA level showed a positive correlation } \\
\text { with AA ( } p<0.001) \text {. Body mass index had a negative correlation with AA ( } r=-0.56 ; p<0.001) \text {. }\end{array}$ & Large \\
\hline $\begin{array}{l}\text { Phillips et } \\
\text { al. }(2015)^{21}\end{array}$ & PA & $\begin{array}{l}\text { PE at school, No control } \\
\text { group/With baseline } \\
\text { 20min vigorous PA }\end{array}$ & 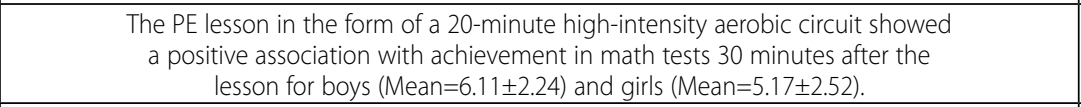 & Large \\
\hline $\begin{array}{l}\text { Castro and } \\
\text { Oliveira } \\
(2016)^{33}\end{array}$ & PF & NA & $\begin{array}{l}\text { Cardiorespiratory endurance and strength showed an association with AA. } \\
\text { Adolescents with low PF levels are twice as likely to have a poor performance } \\
\text { (OR=2.3 95\% p=0.038), when compared to adolescents with high PF levels. When } \\
\text { adjusted for sex and age, only cardiorespiratory endurance was associated. }\end{array}$ & Large \\
\hline $\begin{array}{l}\text { Castro Lopez } \\
\text { et al. }(2016)^{34}\end{array}$ & PF & NA & $\begin{array}{l}\text { The total PF score was positively correlated }(p<0.001) \text { with AA. When stratified by sex, } \\
\text { the correlation with PF was maintained }(r=0.571 \text { female and } r=0.388 \text { male } p<0.001) \text {. By } \\
\text { origin, only immigrants failed to show a significant association in mathematics. }\end{array}$ & Medium \\
\hline $\begin{array}{c}\text { Olivares and } \\
\text { Garcia-Rubio } \\
(2016)^{32}\end{array}$ & PF & NA & $\begin{array}{l}\text { All the PF components showed an association with the AA score, control, sex, SES, region } \\
\text { and type of school. Strength was the PF component with the highest beta value }(B=0.09) \text {. } \\
\text { Flexibility and strength showed an individual association with all the subjects. }\end{array}$ & NA \\
\hline $\begin{array}{l}\text { Faught et } \\
\text { al. }(2017)^{23}\end{array}$ & PA & NA & $\begin{array}{l}\text { Students who followed the recommendations of 3-5 days a week of PA had 33\% less chance } \\
\text { of achieving excellent grades when compared to those who followed the recommendation } \\
\text { for 6-7 days of the week. Moreover, when the frequency of active days of the adolescents } \\
\text { presented was 0-2 days/week, this chance fell to } 51 \% \text {. Control: age, sex, BMl and SES. }\end{array}$ & Medium \\
\hline \begin{tabular}{c|} 
Garcia- \\
Hermoso \\
and Marina \\
$(2017)^{24}$ \\
\end{tabular} & PA & NA & $\begin{array}{l}\text { Association between PA and AA for girls ( } p=0.043 \text { ). When adjusting: age, birth weight, } \\
\text { SES, education and weight of the mother, and screen time, no association was seen. }\end{array}$ & Large \\
\hline $\begin{array}{c}\text { Garcia- } \\
\text { Hermoso et } \\
\text { al. }(2017)^{35}\end{array}$ & PF & NA & $\begin{array}{l}\text { In students with high cardiorespiratory fitness levels and normal weight the chances of } \\
\text { high AA increase by 49.9\%, when compared to low fitness levels and overweight students. } \\
\text { Adjustment: weight, sex and SES. Students with good PF had better chances of achieving } \\
\text { good grades both in languages (OR:1.187/ OR:1.349), and in math (OR:1.444/ OR: 1.728). }\end{array}$ & Large \\
\hline $\begin{array}{l}\text { Oliveira et } \\
\text { al. }(2017)^{38}\end{array}$ & PA/PF & NA & $\begin{array}{l}\text { Adolescents forming the fourth quartile of cardiorespiratory fitness had higher grades in } \\
\text { their native language when compared to the first quartile ( } M \text { diff }=0.36 ; p<0.005 \text { ). }\end{array}$ & Large \\
\hline $\begin{array}{c}\text { Owen et al. } \\
(2018)^{25}\end{array}$ & PA & NA & $\begin{array}{l}\text { Changes in PA showed a positive association with AA scores for girls ( } B= \\
\text { 0.39). The model of analysis was adjusted para BMI, SES and race. }\end{array}$ & Medium \\
\hline
\end{tabular}


girls. Furthermore, it is suggested that this trend may occur in girls due to maturation velocity. ${ }^{41}$ Along the same line, the review by Marques et al., ${ }^{13}$ which assessed cardiorespiratory fitness alone, found two studies that showed a positive association only for girls.

In at least three articles that quantified AA according to academic grades, it was possible to ascertain that the improvement in PF or the level of PA are associated with the increase in grades. ${ }^{28,31,36}$ Even though cross-sectional studies point to a positive relationship between PA, PF and AA, there are few studies that have analyzed this causal relationship. It is important to mention that academic grades are a limitation when comparing studies, as they are affected by the teacher's subjectivity, selection bias and the students' behavior. ${ }^{13}$ This indicates the need for the use of standardized tests to assess AA, in order to facilitate comparisons between studies.

There are two principal theoretical mechanisms to explain the positive impact of PA and improvement in PF scores on AA. The neurophysiological mechanism is based on the improvement in synaptic transmissions, which can increase memory capacity, thereby facilitating learning. ${ }^{42,43}$ The psychosocial mechanism suggests that the improvement in physical test results is associated with components of mental health (self-esteem, self-image and emotional stability) ${ }_{1}^{17,44}$ which consequently has its impact on cognitive aspects.

Most studies had a cross-sectional design, therefore, causality cannot be determined. AA is assessed by academic grades or by means of standardized tests that are suitable for the situation of each country. Therefore, the international comparison is limited. PA is assessed by different self-reported measures, hence comparisons between studies are limited and measurement errors cannot be disregarded. In contrast,
PF is analyzed objectively and by standardized tests, therefore reducing the chances of classification errors. Some studies (8) did not present sufficient data in their analyses to calculate the effect size. As a result, it was not possible to establish this information in its entirety.

Simultaneous assessment of PA and PF as independent variables is recommended. Investigations with samples from developing countries, and the inclusion of possible confounding variables such as sex, age, nutritional status, parental education and SES. The use of these variables can help to improve the accuracy of results.

\section{CONCLUSIONS}

The results of this review suggest that PA and PF are positively associated with adolescent AA. In more than $80 \%$ of the studies that investigated PA or PF as an independent variable, the strength of association was considered strong in relation to the effect size. Studies that assessed PA and PF simultaneously show inconclusive results about which of the variables has the greatest influence on AA, as they represent a small portion of the evidence (13.6\%) and provide discrepant results. The component of PF that showed the highest frequency of association with AA was cardiorespiratory fitness (77.8\%), followed by muscle strength (66.7\%). Studies on PA did not assess time, type, volume and frequency separately, rendering comparisons between components impossible. Regular participation in PA and improvement of PF can produce positive effects on the AA of adolescents.

All authors declare no potential conflict of interest related to this article

AUTHORS' CONTRIBUTIONS: Each author made significant individual contributions to this manuscript. CCR: participated in the conception of the study, peer review proposed by PRISMA, writing and data analysis; EMC: participated in the peer review proposed by PRISMA, writing and data analysis; CRRA: participated as judge in the event of disagreement with PRISMA procedure and in the review of the manuscript; RSR: participated in the critical review of the text. All authors read and approved the final version of the article.

\section{REFERENCES}

1. Laros JA, Marciano JL, de Andrade JM. Fatores que afetam o desempenho na prova de matemática do SAEB: Um estudo multinível. Aval Psicol. 2010;9(2):173-86.

2. Jesus GR, Laros JA. Eficácia escolar: regressão multinível com dados de avaliação em larga escala. Aval Psicol. 2004:3(2):93-106.

3. Curi AZ, Menezes-Filho NA, Faria EM. A relação entre mensalidade escolar e proficiência no ENEM. In: XXXVII Encontro Nacional de Economia. Foz do Iguaçu; 2009

4. Trudeau F, Shephard RJ. Physical education, school physical activity, school sports and academic performance. Int J Behav Nutr Phys Act. 2008;5(10):1-12.

5. Tomporowskia PD, Lambourneb KL, Okumura MS. Physical activity interventions and children's mental function: an introduction and overview. Prev Med. 2011;52(Suppl 1):S3-9.

6. Taras H. Physical activity and student performance at school. J Sch Health. 2005;75(6):214-8.

7. Donnelly JE, Hillman CH, Castelli D, Etnier JL, Lee S, Tomporowski P, et al. Physical activity, fitness, cognitive function, and academic achievement in children: a systematic review. Med Sci Sports Exerc. 2016;48(6):1197-222.

8. Banerjee PA, Lamb S. A systematic review of factors linked to poor academic performance of disadvantaged students in science and maths in schools. Cogent Education 2016;31(1):1178441.

9. Hoehner CM, Soares J, Parra Perez D, Ribeiro IC, Joshu CE, Pratt M, et al. Physical activity interventions in Latin America: a systematic review. Am J Prev Med. 2008; 34(3):224-33.

10. Cureau FV, Da Silva TL, Bloch KV, Fujimori E, Belfort DR, De Carvalho KM, et al. ERICA: Leisure-time physical inactivity in Brazilian adolescents. Rev Saude Publica. 2016; 50(Suppl 1):S1-11.

11. Singh A, Uijtdewilligen L, Twist JW, van Mechelen W, Chinapaw MJ. Physical activity and performance at school: a systematic review of the literature including a methodological quality assessment. Arch Pediatr Adolesc Med. 2012;166(1):49-55.

12. Santana CC, Azevedo LB, Cattuzzo MT, Hill JO, Andrade LP, Prado WL. Physical fitness and academic performance in youth: a systematic review. Scand J Med Sci Sports. 2016;27(6):579-603.

13. Marques A, Santos DA, Hillman CH, Sardinha LB. How does academic achievement relate to cardiorespiratory fitness, self-reported physical activity and objectively reported physical activity: a systematic review in children and adolescents aged 6-18 years. Br J Sports Med. 2018;52(16):1039.

14. Moher D, Libertati A, Tetzlaff J, Altman DG, PRISMA Group. Preferred reporting items for systematic reviews and meta-analyses: the PRISMA statement. PLoS Med. 2009;6(7):e1000097.

15. Downs SH, Black N. The feasibility of creating a checklist for the assessment of the methodological quality both of randomised and non-randomised studies of health care interventions. J Epidemiol Community Health. 1998:52(6):377-84

16. Espírito-Santo H, Daniel F. Calcular e apresentar tamanhos do efeito em trabalhos científicos (3): Guia para reportar os tamanhos do efeito para análises de regressão e ANOVAs. Rev Portug Investig Comportamental e Social. 2018;4(1):43-60.

17. Sigfúsdóttir ID, Kristjánsson AL, Allegrante JP. Health behaviour and academic achievement in Icelandic school children. Health Educ Res. 2007; 22(1):70-80.

18. Fox CK, Barr-Anderson D, Neumark-Sztainer D, Wall M. Physical activity and sports team participation: associations with academic outcomes in middle school and high school students. J Sch Health 2010:80(1):31-7.

19. Stea TH, Torstveit MK. Association of lifestyle habits and academic achievement in Norwegian adolescents: A cross-sectional study. BMC Public Health. 2014;14:829

20. Correa-Burrows $P$, Burrows R, Orellana Y, Ivanovic D. Achievement in mathematics and language is linked to regular physical activity: a population study in Chilean youth. J Sports Sci. 2014;32(17):1631-8.

21. Phillips D, Hannon JC, Castelli DM. Effects of vigorous intensity physical activity on mathematics test performance. J Teach Phys Educ. 2015;34(3):346-62.

22. Bastos F, Reis VM, Aranha AC, Garrido ND. Relation between sport and physical activity, BMI levels, perceptions of success and academic performance. Motricidade. 2015;11(3):41-58.

23. Faught EL, Gleddie D, Storey KE, Davison CM, Veugelers PJ. Healthy lifestyle behaviours are positively and independently associated with academic achievement: An analysis of self-reported data from a nationally representative sample of Canadian early adolescents. PLoS One. 2017;12(7):e0181938.

24. García-Hermoso A, Marina R. Relationship of weight status, physical activity and screen time with academic achievement in adolescents. Obes Res Clin Pract. 2017;11(1):44-50.

25. Owen KB, Parker PD, Astell-Burt T, Lonsdale C. Regular physical activity and educational outcomes in youth: a longitudinal study. J Adolesc Health. 2018;62(3):334-40.

26. London R, Castrechini S. A longitudinal examination of the link between youth physical fitness and academic achievement. J Sch Health. 2011;81(7):400-8.

27. Van Dusen DP, Kelder SH, Kohl HW 3rd, Ranjit N, Perry CL. Associations of physical fitness and academic performance among schoolchildren. J Sch Health. 2011;81(12):733-40.

28. Chen $\perp$, Fox KR, Ku PW, Taun CY. Fitness change and subsequent academic performance in adolescents J Sch Health. 2013;83(9):631-8. 
29. Coe DP, Peterson T, Blair C, Schutten MC, Peddie H. Physical fitness, academic achievement, and socioeconomic status in school-sged youth. J Sch Health. 2013;83(7):500-7.

30. Liao PA, Chang HH, Wang JH, Wu MC. Physical fitness and academic performance: empirical evidence from the National Administrative Senior High School Student Data in Taiwan. Health Educ Res. 2013;28(3):512-22.

31. Bezold CP, Konty KJ, Day SE, Berger M, Harr L, Larkin M, et al. The effects of changes in physical fitness on academic performance among New York City youth. J Adolesc Health. 2014;55(6):774-81.

32. Olivares PR, García-Rubio J. Associations between different components of fitness and fatness with academic performance in Chilean youths. PeerJ. 2016;4:e2560.

33. Castro FJ, Oliveira AC. Association between health-related physical fitness and academic performance in adolescents. Rev Bras Cineantropom Desempenho Hum. 2016;18(4):441-9.

34. Castro López R, Perez Gómez V, Cachon Zagalaz J, Zagalaz Sánchez ML. Associations of academic performance and physical fitness in Zaragoza's adolescent students. Sport TK Rev Euroamericana Cien Deporte. 2016;5(1):47-53.

35. García-Hermoso A, Esteban-Cornejo I, Olloquequi J, Ramírez-Véles R. Cardiorespiratory fitness and muscular strength as mediators of the influence of fatness on academic achievement. J Pediatr. 2017;187:127-33.e3

36. Ardoy DN, Fernández-Rodríguez JM, Jiménez-Pavón D, Castillo R, Ruiz JR, Ortega FB. A Physical Education trial improves adolescents' cognitive performance and academic achievement: The EDUFIT study. Scand J Med Sci Sports. 2014;24(1):52-61.
37. Pellicer-Chenoll M, Garcia-Massó X, Morales J, Serra-Añó P, Solana-Tramunt M, Gonzáles LM, et al. Physical activity, physical fitness and academic achievement in adolescents: a self-organizing maps approach. Health Educ Res. 2015;30(3):436-48.

38. Oliveira T, Pizarro A, Costa M, Fernandes L, Silva G, Mota J, et al. Cardiorespiratory fitness, but not physical activity, is associated with academic achievement in children and adolescents. Ann Hum Biol. 2017;44(4):309-15.

39. Reis RS, Petroski EL, Lopes AS. Medidas da atividade física: revisão de métodos. Rev Bras Cineantropom Desempenho Hum. 2000;2(1):89-96.

40. Guedes DP, Guedes JE. Atividade física, aptidão física e saúde. Rev Bras Ativ Fis Saúde. 1995; 1 (1):18-35.

41. Haapala E, Poikkeus AM, Tompuri T, Kukkonen-Harjula K, Leppanen PH, Lindi V, et al. Associations of motor and cardiovascular performance with academic skills in children. Med Sci Sports Exerc. 2014;46(5):1016-24

42. Winter B, Breitenstein C, Mooren FC, Voelker K, Fobker M, Lechtermann A, et al. High impact running improves learning. Neurobiol Learn Mem. 2007;87(4):597-609.

43. McMorris T, Collard K, Corbett J, Dicks M, Swain JP. A test of the catecholamines hypothesis for an acute exercise-cognition interaction. Pharmacol Biochem Behav. 2008;89(1):106-15.

44. Sallis JF, McKenzie TL, Kolody B, Lewis M, Marshall S, Rosengard P. Effects of health-related physical education on academic achievement: project SPARK. Res Q Exerc Sport. 1999;70(2):127-34. 